\title{
Omega-3 Fatty Acids versus Heavy Metals: A Quantitative Estimation of the Benefit-Risk Ratio for the Consumption of Commonly-Consumed Fish and Products in Metro Manila
}

\author{
Dave P. Briones ${ }^{1}$, and Nancy Lazaro-Llanos ${ }^{2}$ \\ ${ }^{1}$ Food and Nutrition Research Institute, Department of Science and Technology, Bicutan, Taguig City \\ ${ }^{2}$ Chemistry Department, De La Salle University, 2401 Taft Avenue, Manila
}

Fish and other marine products consumption is the main route of heavy metal exposure to human which poses health risks if taken in high dosage. On the other hand, the nutritional benefits of fish are mainly due to the content of high-quality protein and high content of the two kinds of omega-3 polyunsaturated fatty acids (PUFA): eicosapentaenoic acid (EPA) and docosahexaenoic acid (DHA). The study aims to assess and compare the benefit-risk ratio for the consumption of commonly-consumed fish and products in Metro Manila. Fish and product samples were analyzed for moisture, crude fat, heavy metals $(\mathrm{As}, \mathrm{Cd}, \mathrm{Pb}$ ) and fatty acid profile (saturated, mono- and polyunsaturated) including omega-3 fatty acids EPA and DHA. These findings generally indicate that the consumption of fish and products studied posed no risk to human health. Essential fatty acids EPA and DHA were highest for dried anchovy, Stolephorus indicus (1.5 and $7.3 \mathrm{mg} / \mathrm{g}$ sample); mussel, Mytilus smaragdinus (1.5 and $1.0 \mathrm{mg} / \mathrm{g}$ sample); round scad, Decapterus macrosoma (0.9 and $3.4 \mathrm{mg} / \mathrm{g}$ sample); and skipjack tuna, Auxis thazard (1.1 and $3.9 \mathrm{mg} / \mathrm{g}$ sample). The hazard quotients of essential fatty acids versus heavy metals were also less than 1 except for $\mathrm{Cd}$ in squid (1.8), In the case of dried sardine (19.9), squid (1.8), shrimp (3.4), and skipjack tuna (1.7), these foods should be monitored regularly. In conclusion, the target hazard quotients for most of the fish and products showed values less than 1 , which suggest that health risks were insignificant.

Keywords: $\omega-3$ polyunsaturated fatty acids n-3 (PUFA); EPA; DHA; heavy metals; benefit-risk ratio

\section{INTRODUCTION}

Fish is a healthy food because of its nutritional benefits related to its proteins of high biological quality, desirable lipid composition, valuable mineral compounds, and vitamins. The particular composition of its lipid fraction, rich in essential $\omega-3$ polyunsaturated fatty acids (PUFA), especially eicosapentaenoic acid (EPA) and docosahexaenoic acid (DHA), and poor in cholesterol makes it as a primer food (CastroGonzales 2002; Clarkson, 2002; Carvalho, et al., 2005; Domingo, et al., 2007; Castro- 
Gonzales and Mendez-Armenta, 2008; Groth, 2010).

Currently there is major emphasis on the beneficial effects of omega-3 fatty acids in the diet (Yashodhara, et al., 2009). There have been studies showing omega-3 fatty acid involvement in lowering cholesterol levels and blood pressure, which is essential for cardiovascular health (Bonaa, et al., 1990; Horrocks, 1999; Connor, 1994; Stone, 1996; Connor and Connor, 1997; Schmidt, 1997). It has been estimated that consumption of one fatty fish meal per day could result in an omega-3 fatty acid intake of approximately $900 \mathrm{mg} /$ day, an amount shown to lower coronary heart disease mortality rates (KrisEtherton, et al., 2002). Omega-3 fatty acids (EPA) have been proven to have protective effects in reducing arrhythmias and thrombosis (Kinsella, et al., 1990; Oomen, et al., 2000; Kris-Etherton, et al., 2002), lowering plasma triglycerides levels (Harris, 1997; Ismail, 2005) and reducing blood clotting tendency (Agree, et al., 1997; Din, et al., 2004; Ismail, 2005). Studies have shown that omega3 PUFAs appear to improve many metabolic consequences of insulin resistance in humans by lowering hypertension and plasma triglycerides (Berry, 1997). Moreover, fish oil intake has also been associated with a low incidence of diabetes mellitus (Malasanos and Stacopoole, 1991; Rustan, et al., 1997; Toft, 1995). In addition, DHA was also found to be essential for infant brain development and eye function (Birch et al., 1998). There is also a proposed mechanism that involves immune system modulation by DHA to reduce the action of inflammatory compounds (Darlington and Stone, 2001).

Humans cannot synthesize omega-3 fatty acids, instead they have to obtain omega-3 fatty acids from those that pass through the food chain and become incorporated in fish and other marine products. The types and levels of fatty acids found in fish vary with species, age, size, reproduction stage, season, geographical location and diet. Fatty acids from fish are considerably higher in proportions of 20 and 22 carbon chains in comparison with terrestrial animals (Nettleton and Exler, 1992). Saturated fatty acids such as hexadecaenoic acid (palmitic acid 16:0) and octadeconic acid (oleic acid 18:0) are also found in fish in substantial levels. Other fatty acids found to be present are 18:3 $\omega-3,18: 5 \omega-$ 3, 20:4 $\omega-3$, and 22:5 $\omega-3$ (Napolitano, 1998).

The American Heart Association (AHA), as well as various international organizations, has affirmed that omega-3 fatty acids benefit the heart of healthy people, and those at high risk or suffering cardiovascular disease. In 1996, the AHA released its Science Advisory, "Fish Consumption, Fish Oil, Lipids and Coronary Heart Disease" (Stone 1996). The current AHA's dietary guidelines recommend that healthy adults eat at least two servings of fish per week (Kris-Etherton, et al., 2003; KrisEtherton, et al., 2002). However, the Scientific Statement of the AHA also indicates that fish and other seafood are potentially a major source of human exposure to various environmental contaminants such as heavy metals and metalloids. These compounds are of concern due to their toxicity, persistence, bioaccumulation, and biomagnifications into the food chain (Beijir and Jernelov, 1986; Falco et al., 2006; Svenson, et al., 1996 Takhata, et al., 1998; Goyer, 1997; Papanikolau, et al., 2005; Castro-Gonzales, and Mendez-Armeta, 2008; Groth, 2010). The content of toxic heavy metals in fish can counteract the positive effects of the omega-3 fatty acids present (Kris-Etherton, et al, 2003; Chan, et al., 2004).

A variety of contaminants including toxic heavy metals are reported to be ubiquitously present in rivers and reservoirs and are disadvantageous for aquatic organisms (WHO, 1990; Olson, 1998; Carvalho, et al., 2005; Alina et al., 2012). Heavy metals in some commercial fish species from Manila Bay were analyzed by Prudente et al. (2007). In this study, the order of concentration of highly toxic metals in the fish examined were $\mathrm{Hg}>\mathrm{Pb}>\mathrm{Cd}$. Heavy metal analysis in selected fish species collected from Laguna Bay was conducted by Madamba and Pamulaklakin (1994). Results have shown that 
the highest metal concentrations were observed in the inedible tissues, followed by whole tissues, and edible tissues. Santiago et. al. (2009) investigated the mercury levels of widely consumed fish species sold in public market in the Greater Manila Area. Total mercury concentrations were found to be highest in Decarpterus macrosoma (round scad) and with no significant difference in both Chanos chanos (milkfish) and Oreochromis niloticus (tilapia).

In the Philippines, according to the recent National Nutrition Survey, children 6 months to 5 years old consume $7.3 \%$ of fish and products from the total food intake in a day. Children 6 to 12 years old consume $12.7 \%$ of fish and products. Adolescents 13 to 19 years old, adults 20 to 59 years old and elderly 60 years old and older consume $13.4 \%, 14.7 \%$ and $15.6 \%$ of fish and products, respectively (FNRI-DOST, 2010).

A number of researchers have started a quantitative estimation of risk versus benefit of fish intake for human health. Gladyshev, et. al. (2008) derived a formula to quantify the benefit-risk ratio of consuming food containing PUFAs versus that of heavy metals for Siberian grayling (Thymallus arcticus) commonly found in Yenisei River. Foran et al. (2005) estimated benefit-risk ratios for essential fatty acids (EFAs) versus many organic contaminants and methylmercury in wild and farmed salmon. In their calculation, Foran et. al. (2005) used the sum of concentrations for all of the measured contaminants. Besides the sum data, benefitrisk ratios for EFA versus individual organic toxic species, as well as versus heavy metal contents in consumed fish are very useful. Budtz-Jorgensen, et al. (2007) developed a complicated regression model, based on dietary questionnaire responses, clinical tests and neurobehavioral tests for a separation of risks and benefits of fish intake. This model seems to have a further development if supplemented with data on concentrations of given beneficial and risky components, e.g. EFA vs. metals in consumed fish of different species.
The study aims to compare and assess the quantitative estimation of the benefit-risk ratio of some of the commonly-consumed fish and products collected from four wet markets and a supermarket in Metro Manila. Proximate (moisture and crude fat) analyses, fatty acid profile and heavy metals composition of fish and products can serve as qualitative data that can be used for the food and nutrition researches. The study will also give quantitative estimation of risks versus benefits of fish intake for human health.

\section{MATERIALS AND METHODS}

Reagents and Materials Preparation. Fish and other marine products were collected and prepared from 4 wet markets and a supermarket in Metro Manila. Samples include: Stolephorus indicus (anchovy), Sardinella longiceps (sardine), Mytilus smaragdinus (mussel), Loligo pealei (squid), Metapeneaus emsis (shrimp), Decapterus macrosoma (round scad), Chanos chanos (milkfish), Auxis thazard (skipjack tuna), and Oreochromis niloticus (tilapia). The samples were washed, cleaned and scales were removed. Weight, dimension, and percent edible portion of samples were measured. Samples were pooled, ground and mixed thoroughly before taking sub-samples for analyses. Only edible portions were used in all the analyses. Portions were taken for moisture determination using AOAC International Official Methods for Analysis (Horwitz, 2000).

Acid Hydrolysis and Fat Extraction. Fish samples were weighed into a $250-\mathrm{mL}$ digestion tube containing approximately 1 gram Celite. Acid hydrolysis was done using the Soxtec System 1047 Hydrolyzing Unit. Fat extraction cup was heated at $105^{\circ} \mathrm{C}$ for 2 hours in the drying oven and was cooled in a desiccator for 30 minutes and weighed. The fat from the residue was extracted using the Soxtec System HT6 1043. Fat extraction was done with thimbles immersed in $50 \mathrm{~mL}$ ether and boiled for about 15 minutes. Fat extraction of sample with thimble was continued in the rinsing position for another 30 minutes. After extraction, the extraction cup with fat was removed from the Soxtec 
System. The extraction cup was placed inside a fume hood and was allowed to dry, then dried in an oven at $105^{\circ} \mathrm{C}$ for 2 hours, cooled for 30 minutes in a desiccator and will be weighed (Tecator Manual 1043; Tecator Manual 1047).

\section{Heavy Metals (As, Cd, Pb,) Analyses by Graphite Furnace Atomizer-AAS.} Approximately 2 grams of sample was weighed in a digestion vessel. A volume of 5 $\mathrm{mL}$ concentrated nitric acid and $2 \mathrm{~mL} \mathrm{30 \%}$ hydrogen peroxide were added to the sample. Digestion vessels were arranged in a digestion rack and placed inside the microwave digestor (AOAC Official Method 999.10). Digests were diluted to volume. A blank was included in every set. Intermediate standards and working standards used were $10 \mathrm{ppm}$ and 200 ppb for As and $\mathrm{Pb} ; 10 \mathrm{ppm}$ and $100 \mathrm{ppm}$ for Cd. Accurately $20 \mu \mathrm{L}$ of the standard and sample were injected until finished.

Method Suitability Test for Omega-3 PUFAs. Method suitability test of omega-3 PUFAs (EPA and DHA) were done using 4 saponification and transesterification method. FAPAS T1496 fish oil with consensus value for EPA and DHA was used for the method suitability test for quality assurance. The best method was tested to compare with the current method being used for fatty acid profile analysis. FAPAS T1464 vegetable oil with consensus value for total saturated, total mono- and polyunsaturated fatty acids was used for quality assurance.

Fatty Acid Profile Analysis. Saponification and transesterification were conducted based on AOAC method (AOAC Official Method 991.39; AOAC Official Method 996.06) as follows: $1 \mathrm{~g}$ of dried food sample or $25 \mathrm{mg}$ of fish oil were placed into a $20 \mathrm{~mL}$ screw top glass tube to which $0.7 \mathrm{~mL}$ of $10 \mathrm{M} \mathrm{KOH}$, and $5.3 \mathrm{~mL}$ of methanol was added. The tubes were incubated in a $55^{\circ} \mathrm{C}$ water bath for 1.5 hour with vigorous hand-shaking for 5 seconds every 20 minutes to properly permeate, dissolve, and hydrolyze the sample. After cooling to below room temperature in a water bath containing tap water, $0.58 \mathrm{~mL}$ of
$12 \mathrm{M} \mathrm{H}_{2} \mathrm{SO}_{4}$ was added. The tubes were mixed by inversion and when the precipitate appeared, the tubes were incubated again in a $55^{\circ} \mathrm{C}$ water bath for 1.5 hours with handshaking for 5 seconds every 20 minutes. The tubes were cooled in a water bath containing tap water. To extract the fatty acid methyl esters (FAMEs) $3 \mathrm{~mL}$ of hexane was added to the tubes which were vortex-mixed for $5 \mathrm{~min}$. The hexane layer containing the FAMEs was dried with anhydrous sodium sulfate. The upper layer of hexane was transferred into a GC vial.

Working standard was prepared by accurately weighing 0.01 to $0.1 \mathrm{~g}$ each of the methyl ester standard into $25 \mathrm{~mL}$ volumetric flask and diluted to volume with hexane. The standards used were caproic acid methyl ester (C6), caprylic acid methyl ester (C8), capric acid methyl ester (C10), lauric acid methyl ester (C12), myristic acid methyl ester (C14), palmitic acid methyl ester (C16), stearic acid methyl ester (C18), oleic acid methyl ester (C18:1), linoleic acid methyl ester (C18:2), linolenic acid methyl ester (C18:3), arachidic acid methyl ester (C20), behenic acid methyl ester (C22), docosahexaenoic acid methyl ester (C22:6) and lignoceric acid methyl ester (C24). Calibration standards for eicosapentaenoic acid (C20:5) and docosahexaenoic acid (C22:6) were prepared by quantitatively transferring $20,40,60,80$ and $100 \mu \mathrm{L}$ of the working standard in $1 \mathrm{~mL}$ volumetric flask and were diluted with heptane to volume.

Gas chromatograph used was equipped with abonded phase capillary column, oxygen scrubber in carrier gas line, flame ionization detector and temperature programmable oven from $50^{\circ} \mathrm{C}$ to $250^{\circ} \mathrm{C}$. Hydrogen gas was used as carrier gas with 1.2 to $1.5 \mathrm{~mL}$ per minute flow rate. CP-Sil88 capillary column was used with a $100 \mathrm{~m}$ length, $0.25 \mathrm{~mm}$ internal diameter and $0.25 \mu \mathrm{m}$ film thickness. The column was coated with $100 \%$ cyanopropylpolysiloxane and was purchased from Chrompack. Injector was set at $280^{\circ} \mathrm{C}$, detector at $300^{\circ} \mathrm{C}$ and the oven temperature will be gradient. Initial temperature was $60^{\circ} \mathrm{C}$ with holding time of 5 minutes; it was then be 
heated to $165^{\circ} \mathrm{C}$ at a rate of $15^{\circ} \mathrm{C}$ per minute and with holding time of 1 minute and the final temperature was increased to $225^{\circ} \mathrm{C}$ at a rate of $2^{\circ} \mathrm{C}$ per minute and with holding time of 17 minutes. The total run time was 61 minutes. From the above analysis, the concentration of each fatty acid methyl ester was automatically computed by the instrument using corrected normalization based on the area of the standard and area of the sample. Individual fatty acid concentration was compared by multiplying the fatty acid methyl ester concentration with the stoichiometric factor, which is the ratio of the molecular weights of fatty acid and fatty acid methyl ester.

Target Hazard Quotient (THQ). The formula derived by Gladyshev, et al., (2008) was used to estimate the benefit-risk ratio for the consumption of fish and products (THQ) as follows:

$$
\begin{aligned}
& \mathrm{FP}=\frac{\mathrm{R}_{\mathrm{EFA}}}{\mathrm{C}} \\
& \mathrm{DM}=\mathrm{FP} \times \mathrm{c} \\
& \mathrm{HQ}=\frac{\mathrm{DM}}{\mathrm{RfD} \times \mathrm{AQ}} \\
& \mathrm{HQ}_{\mathrm{EFA}}=\frac{R_{E F A} \times c}{C \times R f D \times A W}
\end{aligned}
$$

where $\mathrm{FP}=$ fish portion, $\mathrm{g} /$ day; $\mathrm{R}_{\mathrm{EFA}}=$ recommended daily consumption of EPA + DHA, $1000 \mathrm{mg}$; $\mathrm{C}=$ content of $\mathrm{EPA}+$ DHA in a given fish, $\mathrm{mg} / \mathrm{g}$; $\mathrm{DM}=$ dose of metal, $\mu \mathrm{g} /$ day; $\mathrm{c}=$ content of a given metal in a given fish, $\mu \mathrm{g} / \mathrm{g}$; RfD $=$ reference dose (maximum tolerable daily intake of a specific metal that does not result in any deleterious health effects, $\mu \mathrm{g} / \mathrm{kg} /$ day; $\mathrm{AW}=$ average adult weight; HQEFA represents a hazard quotient for fish consumption when a human person aims to obtain from the fish the recommended dose of EFA or what is called risk-benefit ration for fish consumption due to metal and EFA intake, respectively. Evidently, $\mathrm{HQ}_{\mathrm{EFA}}<1$ means the health benefit from fish consumption, and $\mathrm{HQ}_{\mathrm{EFA}}>1$ means the risk.

\section{RESULTS}

Fish Samples and Proximate Analysis. The properties of the fish and product samples, percent moisture and percent crude fat are shown in Table 1. Percentage moisture was determined using AOAC 952.08A (Horwitz, 2005). The method is applicable to all marine products except for oyster. Milkfish, dried sardine, dried anchovy, skipjack tuna and round scad have the highest crude fat content among the fish and products.

Heavy Metal Levels in Fish and Products. The method used for heavy metals analysis was previously validated following the requirements of AOAC, NATA and Eurachem. FAPAS T0774 canned fish was used as a quality control test material to ensure the quality of data generated and was used every batch analysis.

The concentrations of different metals (As, $\mathrm{Cd}, \mathrm{Pb})(\mu \mathrm{g} / \mathrm{g}$ wet weight) in the edible portions of fish and products are given in Table 2. Evidently, dried anchovy has the highest $\mathrm{Cd}$ and $\mathrm{Pb}$ content since the fish is in the dried form. However, the heavy metal contents of dried anchovy are still below the maximum residue limit for fish set by the Joint FAO/WHO Expert Committee on Food Additives (JECFA) (FAO/WHO, 2005) and the European Community (EEC, 2001). Next to dried anchovy, squid, dried Indian sardine and mussel have the highest content of Cd. Cadmium was detected in the lowest amount in the edible tissues of the studied fish and products. The lowest $\mathrm{Cd}$ level was found in shrimp with $0.001 \mu \mathrm{g} / \mathrm{g}$ wet weight. It has been established that $\mathrm{Cd}$ occurs in the aquatic organisms and marine environment in trace concentrations (Burger, et al., 2008). A study of Bustamante et al. (2002) found out that the major part of cadmium is associated with lysosomes and cystolic proteins which play a key function in the storage and detoxification of this element.

High levels of As contents were observed for all fish and products. According to literature, 
$80-90 \%$ of arsenic in seafood is in organic form which is less toxic compared to the inorganic form (Abernathy et. al., 2003; Al Rmalli et al., 2005). Dried Indian sardine was observed to have the highest level of As. The influence of species and feeding habits on As accumulation is not clear in marine mammals. But a study of Storelli and Marcotrigiano (2004) revealed that organisms feeding on crustaceans and algae (such as Indian sardine) appear to retain arsenic concentrations than piscivorous species and the highest levels are found in muscle tissues.
Fresh water habitant milkfish and tilapia showed lower levels of heavy metals (As, Cd and $\mathrm{Pb}$ ) as compared to other seafood. This may be due to the reality that seas and oceans are the larger bodies of water and a wider basin of more contaminants compared to smaller lakes and estuaries. The relatively lower levels of $\mathrm{Cd}$ and $\mathrm{Pb}$ in bangus may be due to the fact that milkfish stays near the surface of the water where they feed on phytoplanktons. Milkfish is a pelagic fish while tilapia is said to be benthic fish. Benthic fish dwells on the bottom where contaminants are found more concentrated (Storelli, 2008).

Table 1. General information of fish and products, percentage moisture and percentage crude fat.

\begin{tabular}{|c|c|c|c|c|c|c|c|}
\hline $\begin{array}{c}\text { Common } \\
\text { Name and } \\
\text { Local Name }\end{array}$ & $\begin{array}{l}\text { Scientific } \\
\text { Name }\end{array}$ & $\begin{array}{l}\text { Length } \\
(\mathrm{cm})\end{array}$ & $\begin{array}{c}\text { Width } \\
\text { (cm) }\end{array}$ & $\begin{array}{l}\text { Weight } \\
\text { (g) }\end{array}$ & $\begin{array}{c}\text { Percentage } \\
\text { Edible } \\
\text { Portion } \\
(\%)\end{array}$ & $\begin{array}{c}\text { Percentage } \\
\text { Moisture } \\
(\%)\end{array}$ & $\begin{array}{l}\text { Percentage } \\
\text { Crude Fat } \\
(\%)\end{array}$ \\
\hline $\begin{array}{c}\text { anchovy } \\
\text { (dried dilis) }\end{array}$ & $\begin{array}{l}\text { Stolephorus } \\
\text { indicus }\end{array}$ & $48-70$ & $8-10$ & $\begin{array}{l}0.34- \\
1.03 \\
\end{array}$ & 100 & 17.90 & 3.99 \\
\hline $\begin{array}{l}\text { dried sardine } \\
\text { (dried } \\
\text { tamban, } \\
\text { Indian } \\
\text { sardine) }\end{array}$ & $\begin{array}{c}\text { Sardinella } \\
\text { longiceps }\end{array}$ & $38-60$ & $25-30$ & $\begin{array}{l}8.04- \\
12.85\end{array}$ & $46-52$ & 40.22 & 5.93 \\
\hline $\begin{array}{c}\text { Mussel } \\
\text { (tahong) }\end{array}$ & $\begin{array}{c}\text { Mytilus } \\
\text { smaragdinus }\end{array}$ & $55-65$ & $28-32$ & $\begin{array}{l}7.09- \\
11.84\end{array}$ & - & 85.18 & 1.72 \\
\hline Squid (pusit) & Loligo pealei & $95-180$ & $20-35$ & $\begin{array}{l}29.23- \\
33.45\end{array}$ & $95-97$ & 87.39 & 1.05 \\
\hline $\begin{array}{l}\text { Shrimp, } \\
\text { greasy back } \\
\text { (hipong } \\
\text { swahe) } \\
\text { (shrimp, } \\
\text { greasy back) }\end{array}$ & $\begin{array}{l}\text { Metapeneaus } \\
\text { emsis }\end{array}$ & - & - & $\begin{array}{l}11.36- \\
16.86\end{array}$ & $49-63$ & 85.07 & 0.48 \\
\hline $\begin{array}{l}\text { Galunggong } \\
\text { (round scad) }\end{array}$ & $\begin{array}{l}\text { Decapterus } \\
\text { macrosoma }\end{array}$ & $70-210$ & $35-40$ & $\begin{array}{l}100.93- \\
128.13 \\
\end{array}$ & $59-65$ & 72.13 & 3.02 \\
\hline $\begin{array}{l}\text { Bangus } \\
\text { (milkfish) }\end{array}$ & $\begin{array}{l}\text { Chanos } \\
\text { chanos }\end{array}$ & $\begin{array}{c}370- \\
380\end{array}$ & 85 & $\begin{array}{l}458.68- \\
588.51\end{array}$ & $54-59$ & 68.36 & 10.02 \\
\hline $\begin{array}{c}\text { Skipjack } \\
\text { tuna, } \\
\text { frigate/bullet, } \\
\text { (tambakol } \\
\text { tulingan) }\end{array}$ & $\begin{array}{l}\text { Auxis } \\
\text { thazard }\end{array}$ & $\begin{array}{l}240- \\
260\end{array}$ & $45-55$ & $\begin{array}{l}218.72- \\
269.18\end{array}$ & $57-61$ & 69.83 & 3.48 \\
\hline Tilapia & $\begin{array}{l}\text { Oreochromis } \\
\text { niloticus }\end{array}$ & $\begin{array}{l}210- \\
215\end{array}$ & 80 & $\begin{array}{l}281.46- \\
304.33\end{array}$ & $36-38$ & 77.40 & 2.06 \\
\hline
\end{tabular}


Table 2. Range of concentrations ( $\mu \mathrm{g} / \mathrm{g}$ raw weight) of heavy metals $(\mathrm{n}=3)$.

\begin{tabular}{|c|c|c|c|}
\hline \multirow{2}{*}{ Fish and Products } & \multicolumn{3}{|c|}{ Heavy metals content $(\mu \mathrm{g} / \mathrm{g})$} \\
\hline & As & $\mathrm{Cd}$ & $\mathrm{Pb}$ \\
\hline $\begin{array}{l}\text { Stolephorus indicus } \\
\text { (anchovy) }\end{array}$ & $0.910 \pm 0.091$ & $0.273 \pm 0.002$ & $0.154 \pm 0.023$ \\
\hline $\begin{array}{c}\text { Sardinella longiceps } \\
\text { (sardine, Indian } \\
\text { sardine) }\end{array}$ & $9.282 \pm 0.462$ & $0.054 \pm 0.052$ & $0.056 \pm 0.009$ \\
\hline $\begin{array}{c}\text { Mytilus smaragdinus } \\
\text { (mussel) }\end{array}$ & $0.572 \pm 0.046$ & $0.034 \pm 0.002$ & $0.030 \pm 0.004$ \\
\hline $\begin{array}{l}\text { Loligo pealei } \\
\text { (squid) }\end{array}$ & $0.464 \pm 0.042$ & $0.064 \pm 0.002$ & $0.021 \pm 0.002$ \\
\hline $\begin{array}{c}\text { Metapeneaus emsis } \\
\text { (shrimp) }\end{array}$ & $0.720 \pm 0.066$ & $0.0003 \pm 0.0003$ & $0.099 \pm 0.019$ \\
\hline $\begin{array}{l}\text { Decapterus macrosoma } \\
\text { (round scad) }\end{array}$ & $0.414 \pm 0.054$ & $0.008 \pm 0.0006$ & $0.065 \pm 0.018$ \\
\hline $\begin{array}{c}\text { Chanos chanos } \\
\text { (bangus) }\end{array}$ & $0.065 \pm 0.013$ & $0.005 \pm 0.005$ & $0.029 \pm 0.011$ \\
\hline $\begin{array}{l}\text { Auxis thazard } \\
\text { (skipjack tuna) }\end{array}$ & $0.604 \pm 0.059$ & $0.026 \pm 0.002$ & $0.036 \pm 0.002$ \\
\hline $\begin{array}{c}\text { Oreochromis niloticus } \\
\text { (tilapia) }\end{array}$ & $0.044 \pm 0.010$ & $0.011 \pm 0.0003$ & $0.055 \pm 0.010$ \\
\hline $\begin{array}{c}\text { Quality control } \\
\text { (reference material or } \\
\text { spiking) }\end{array}$ & $414-473$ & $1.73-3.27$ & $87-97 \%$ \\
\hline $\begin{array}{l}\text { Consensus value } \\
(\mu \mathrm{g} / \mathrm{g}), \% \text { recovery } \\
\text { range }\end{array}$ & $214-474$ & $1.45-3.72$ & \\
\hline
\end{tabular}

$*$ Mean \pm SEM

Fresh water habitant milkfish and tilapia showed lower levels of heavy metals (As, Cd and $\mathrm{Pb}$ ) as compared to other seafood. This may be due to the reality that seas and oceans are the larger bodies of water and a wider basin of more contaminants compared to smaller lakes and estuaries. The relatively lower levels of $\mathrm{Cd}$ and $\mathrm{Pb}$ in bangus may be due to the fact that milkfish stays near the surface of the water where they feed on phytoplanktons. Milkfish is a pelagic fish while tilapia is said to be benthic fish. Benthic fish dwells on the bottom where contaminants are found more concentrated (Storelli, 2008).

Fatty Acid Profile. Fatty acid compositions of fish and products are presented in Table 3.
Among saturated fatty acids, the largest concentration was for palmitic acid (C16:0), varying from 0.455 to $6.780 \mathrm{mg} / \mathrm{g}$ sample. Dried anchovy, round scad, and skipjack tuna have the highest palmitic acid among the salt water seafood with $6.528,5.861$, and 6.358 $\mathrm{mg} / \mathrm{g}$ wet weight, respectively. Fresh water milkfish and tilapia are also high in palmitic acid with 6.780 and $4.629 \mathrm{mg} / \mathrm{g}$ sample, respectively. Concerning the monounsaturated

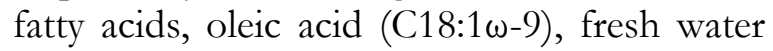
fishes milkfish and tilapia have the highest content compared to the salt water seafood. Milkfish and tilapia gave 5.873 and 5.092 $\mathrm{mg} / \mathrm{g}$ sample, respectively. Among the polyunsaturated fatty acids (PUFA), the outstanding results were linoleic acid (C18:2 $\omega$ - 
6), $13.144 \mathrm{mg} / \mathrm{g}$ and docosahexenoic acid

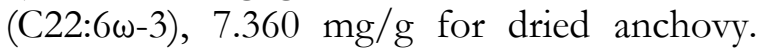
Fresh water milkfish posed the highest level

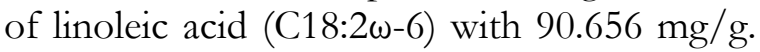
This high concentration of linolenic acid of milkfish may be due to fish feeds that are given to them. Docosahexaenoic acid (C22:6w-3), were also high for round scad and skipjack tuna which are deep sea habitants. Essential fatty acid eicosapentaenoic acid

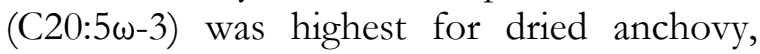
mussel and skipjack tuna with 1.517, 1.543, and $1.085 \mathrm{mg} / \mathrm{g}$ sample, respectively.

Hazard Quotient of Essential Fatty Acids Versus Heavy Metals. Table 4 shows the hazard quotient of essential fatty acids versus heavy metals from the consumption of fish and products. Values of $\mathrm{HQ}_{\mathrm{EFA}}$ for all the metals were less than 1 except for $\mathrm{Cd}$ in squid, and $A s$ in dried sardine, squid, shrimp and skipjack tuna, which means that the consumption of fish and products given has no deleterious health effects if to obtain the recommended portion of essential fatty acids. If hazard quotients of essential fatty acids versus $\mathrm{Cd}$ and $\mathrm{As}$ are to be considered, consumption of squid, dried sardine, shrimp and skipjack tuna for that particular sampling time and sampling site posed a risk to human health. This may be due to its high heavy metals content relative to its omega-3 fatty acids content.

Table 3. Fatty acid profile of the fish and products $(n=3)$

\begin{tabular}{|c|c|c|c|c|c|c|c|c|c|}
\hline $\begin{array}{c}\text { Fatty } \\
\text { acids } \\
\text { (mg/g } \\
\text { sample) }\end{array}$ & $\begin{array}{c}\text { Stolephorus } \\
\text { indicus } \\
\text { (anchovy) }\end{array}$ & $\begin{array}{c}\text { Sardinella } \\
\text { longiceps } \\
\text { (sardine, } \\
\text { Indian } \\
\text { sardine) }\end{array}$ & $\begin{array}{c}\text { Mytilus } \\
\text { smaragdinu } \\
\text { (mussel) }\end{array}$ & $\begin{array}{c}\text { Loligo } \\
\text { pealli } \\
\text { (squid) }\end{array}$ & $\begin{array}{c}\text { Metapeneaus } \\
\text { emsis } \\
\text { (shrimp) }\end{array}$ & $\begin{array}{l}\text { Decapterus } \\
\text { macrosoma } \\
\text { (round } \\
\text { scad) }\end{array}$ & $\begin{array}{l}\text { Chanos } \\
\text { chanos } \\
\text { (milkfish) }\end{array}$ & $\begin{array}{c}\text { Auxis } \\
\text { thazard } \\
\text { (skipjack } \\
\text { tuna) }\end{array}$ & $\begin{array}{c}\text { Oreochromis } \\
\text { niloticus } \\
\text { (tilapia) }\end{array}$ \\
\hline C6:0 & - & $\begin{array}{c}0.097 \\
\pm 0.001\end{array}$ & - & $\begin{array}{c}0.025 \\
\pm 0.000\end{array}$ & $\begin{array}{c}0.013 \\
\pm 0.003\end{array}$ & $\begin{array}{c}0.050 \\
\pm 0.000\end{array}$ & $\begin{array}{c}0.222 \\
\pm 0.002\end{array}$ & $\begin{array}{c}0.059 \\
\pm 0.002\end{array}$ & $\begin{array}{c}0.040 \\
\pm 0.001\end{array}$ \\
\hline C8:0 & $\begin{array}{c}0.029 \\
\pm 0.000\end{array}$ & $\begin{array}{c}0.022 \\
\pm 0.000 \\
\end{array}$ & $\begin{array}{c}0.011 \\
\pm 0.000\end{array}$ & - & $\begin{array}{c}0.006 \\
\pm 0.000 \\
\end{array}$ & $\begin{array}{c}0.009 \\
\pm 0.000 \\
\end{array}$ & - & $\begin{array}{c}0.036 \\
\pm 0.000 \\
\end{array}$ & $\begin{array}{c}0.018 \\
\pm 0.004 \\
\end{array}$ \\
\hline C10:0 & $\begin{array}{c}0.016 \\
\pm 0.000\end{array}$ & $\begin{array}{c}0.139 \\
\pm 0.002\end{array}$ & $\begin{array}{c}0.017 \\
\pm 0.000\end{array}$ & - & $\begin{array}{c}0.009 \\
\pm 0.000\end{array}$ & $\begin{array}{c}0.014 \\
\pm 0.001\end{array}$ & $\begin{array}{c}0.023 \\
\pm 0.001\end{array}$ & $\begin{array}{c}0.011 \\
\pm 0.001\end{array}$ & $\begin{array}{c}0.039 \\
\pm 0.001\end{array}$ \\
\hline C12:0 & $\begin{array}{c}0.036 \\
\pm 0.000 \\
\end{array}$ & $\begin{array}{c}0.087 \\
\pm 0.000 \\
\end{array}$ & $\begin{array}{c}0.099 \\
\pm 0.001 \\
\end{array}$ & $\begin{array}{c}0.012 \\
\pm 0.000 \\
\end{array}$ & $\begin{array}{c}0.065 \\
\pm 0.001 \\
\end{array}$ & $\begin{array}{c}0.133 \\
\pm 0.003 \\
\end{array}$ & $\begin{array}{c}0.861 \\
\pm 0.003 \\
\end{array}$ & $\begin{array}{c}0.014 \\
\pm 0.000 \\
\end{array}$ & $\begin{array}{c}0.910 \\
\pm 0.001 \\
\end{array}$ \\
\hline C14:0 & $\begin{array}{c}1.197 \\
\pm 0.046\end{array}$ & $\begin{array}{c}1.326 \\
\pm 0.007\end{array}$ & $\begin{array}{c}0.900 \\
\pm 0.023\end{array}$ & $\begin{array}{c}0.156 \\
\pm 0.014\end{array}$ & $\begin{array}{c}0.074 \\
\pm 0.001\end{array}$ & $\begin{array}{c}0.836 \\
\pm 0.004\end{array}$ & $\begin{array}{c}1.236 \\
\pm 0.001\end{array}$ & $\begin{array}{c}1.309 \\
\pm 0.010\end{array}$ & $\begin{array}{c}1.103 \\
\pm 0.001\end{array}$ \\
\hline C16:0 & $\begin{array}{c}6.528 \\
\pm 0.054\end{array}$ & $\begin{array}{c}2.854 \\
\pm 0.010\end{array}$ & $\begin{array}{c}2.440 \\
\pm 0.045\end{array}$ & $\begin{array}{c}1.741 \\
\pm 0.028\end{array}$ & $\begin{array}{c}0.455 \\
\pm 0.001\end{array}$ & $\begin{array}{c}5.861 \\
\pm 0.026\end{array}$ & $\begin{array}{c}6.780 \\
\pm 0.006\end{array}$ & $\begin{array}{c}6.358 \\
\pm 0.102\end{array}$ & $\begin{array}{c}4.629 \\
\pm 0.027\end{array}$ \\
\hline C18:0 & $\begin{array}{c}2.417 \\
\pm 0.233\end{array}$ & $\begin{array}{c}0.673 \\
\pm 0.004\end{array}$ & $\begin{array}{c}0.745 \\
\pm 0.046\end{array}$ & $\begin{array}{c}0.581 \\
\pm 0.024\end{array}$ & $\begin{array}{c}0.427 \\
\pm 0.001\end{array}$ & $\begin{array}{c}2.071 \\
\pm 0.087\end{array}$ & $\begin{array}{c}1.192 \\
\pm 0.048\end{array}$ & $\begin{array}{r}2.627 \\
\pm 0.1\end{array}$ & $\begin{array}{c}1.155 \\
\pm 0.076\end{array}$ \\
\hline C18:1 & $\begin{array}{c}1.332 \\
\pm 0.004 \\
\end{array}$ & $\begin{array}{c}0.390 \\
\pm 0.007 \\
\end{array}$ & $\begin{array}{c}0.218 \\
\pm 0.005 \\
\end{array}$ & $\begin{array}{c}0.138 \\
\pm 0.007 \\
\end{array}$ & $\begin{array}{c}0.164 \\
\pm 0.001 \\
\end{array}$ & $\begin{array}{c}2.484 \\
\pm 0.053 \\
\end{array}$ & $\begin{array}{l}5.873 \\
\pm 0.01 \\
\end{array}$ & $\begin{array}{c}2.619 \\
\pm 0.034 \\
\end{array}$ & $\begin{array}{c}5.093 \\
\pm 0.031 \\
\end{array}$ \\
\hline $\mathrm{C} 18: 2$ & $\begin{array}{l}13.144 \\
\pm 0.054\end{array}$ & $\begin{array}{c}5.493 \\
\pm 0.293 \\
\end{array}$ & $\begin{array}{c}3.315 \\
\pm 0.125\end{array}$ & $\begin{array}{c}0.395 \\
\pm 0.001\end{array}$ & $\begin{array}{c}0.742 \\
\pm 0.021\end{array}$ & $\begin{array}{c}8.083 \\
\pm 0.125\end{array}$ & $\begin{array}{l}90.656 \\
\pm 1.217\end{array}$ & $\begin{array}{c}1.208 \\
\pm 0.010\end{array}$ & $\begin{array}{c}4.961 \\
\pm 0.078\end{array}$ \\
\hline C18:3 & $\begin{array}{c}0.550 \\
\pm 0.001 \\
\end{array}$ & $\begin{array}{c}0.283 \\
\pm 0.000 \\
\end{array}$ & $\begin{array}{c}0.144 \\
\pm 0.003 \\
\end{array}$ & $\begin{array}{c}0.066 \\
\pm 0.000 \\
\end{array}$ & $\begin{array}{c}0.059 \\
\pm 0.001 \\
\end{array}$ & $\begin{array}{c}0.183 \\
\pm 0.001 \\
\end{array}$ & $\begin{array}{c}0.330 \\
\pm 0.001 \\
\end{array}$ & $\begin{array}{l}0.715 \\
\pm 0.02 \\
\end{array}$ & $\begin{array}{c}0.651 \\
\pm 0.001 \\
\end{array}$ \\
\hline C20:0 & - & $\begin{array}{c}0.048 \\
\pm 0.000\end{array}$ & - & - & $\begin{array}{c}0.009 \\
\pm 0.000\end{array}$ & - & - & - & - \\
\hline C20:5 & $\begin{array}{c}1.517 \\
\pm 0.040\end{array}$ & $\begin{array}{l}0.379 \\
\pm 0.001 \\
\end{array}$ & $\begin{array}{l}1.543 \\
\pm 0.05\end{array}$ & $\begin{array}{l}0.180 \\
\pm 0.04\end{array}$ & $\begin{array}{l}0.187 \\
\pm 0.002 \\
\end{array}$ & $\begin{array}{c}0.882 \\
\pm 0.002 \\
\end{array}$ & $\begin{array}{l}0.106 \\
\pm 0.003 \\
\end{array}$ & $\begin{array}{r}1.085 \\
\pm 0.002 \\
\end{array}$ & $\begin{array}{c}0.059 \\
\pm 0.002 \\
\end{array}$ \\
\hline C22:0 & - & - & - & - & - & - & - & - & - \\
\hline $\mathrm{C} 24: 0$ & $\begin{array}{l}0.233 \\
\pm 0.001\end{array}$ & $\begin{array}{l}0.014 \\
\pm 0.000\end{array}$ & $\begin{array}{l}0.064 \\
\pm 0.003\end{array}$ & $\begin{array}{l}0.019 \\
\pm 0.000\end{array}$ & $\begin{array}{l}0.022 \\
\pm 0.000\end{array}$ & $\begin{array}{l}0.034 \\
\pm 0.000\end{array}$ & $\begin{array}{l}0.098 \\
\pm 0.001\end{array}$ & - & - \\
\hline C22:6 & $\begin{array}{l}7.360 \\
\pm 0.233\end{array}$ & $\begin{array}{l}0.707 \\
\pm 0.009\end{array}$ & $\begin{array}{r}1.022 \\
\pm 0.039\end{array}$ & $\begin{array}{l}0.417 \\
\pm 0.036\end{array}$ & $\begin{array}{l}0.313 \\
\pm 0.005 \\
\end{array}$ & $\begin{array}{l}3.407 \\
\pm 0.063\end{array}$ & $\begin{array}{l}0.413 \\
\pm 0.005\end{array}$ & $\begin{array}{l}3.860 \\
\pm 0.027\end{array}$ & $\begin{array}{l}0.534 \\
\pm 0.001\end{array}$ \\
\hline \multicolumn{5}{|c|}{ Fatty Acid } & \multicolumn{2}{|c|}{$\begin{array}{c}\text { Consensus Value } \\
\text { (g/100 g oil })\end{array}$} & \multicolumn{3}{|c|}{$\begin{array}{c}\text { Range of Results using Method } 4 \\
\text { (g/100g oil) }\end{array}$} \\
\hline \multicolumn{5}{|c|}{ EPA } & \multicolumn{2}{|c|}{$12.1-14.7$} & \multicolumn{3}{|c|}{$12.3-13.1$} \\
\hline \multicolumn{5}{|c|}{ DHA } & \multicolumn{2}{|c|}{$10.2-12.5$} & \multicolumn{3}{|c|}{$11.7-12.2$} \\
\hline
\end{tabular}

$*$ Mean \pm SEM 
Table 4. Hazard quotient of essential fatty acids versus heavy metals

\begin{tabular}{|c|c|c|c|}
\hline \multirow{2}{*}{$\begin{array}{l}\text { Fish and } \\
\text { Products }\end{array}$} & \multicolumn{3}{|c|}{ Hazard Quotient } \\
\hline & As & Cd & $\mathrm{Pb}$ \\
\hline $\begin{array}{l}\text { Stolephorus } \\
\text { indicus } \\
\text { (anchovy) }\end{array}$ & 0.239 & 0.512 & 0.081 \\
\hline $\begin{array}{c}\text { Sardinella } \\
\text { longiceps } \\
\text { (sardine, Indian } \\
\text { sardine) } \\
\end{array}$ & 19.924 & 0.829 & 0.240 \\
\hline $\begin{array}{c}\text { Mytilus } \\
\text { smaragdinus } \\
\text { (mussel) }\end{array}$ & 0.520 & 0.223 & 0.055 \\
\hline $\begin{array}{l}\text { Loligo pealei } \\
\text { (squid) }\end{array}$ & 1.814 & 1.775 & 0.168 \\
\hline $\begin{array}{l}\text { Metapeneaus emsis } \\
\text { (shrimp) }\end{array}$ & 3.360 & 0.011 & 0.921 \\
\hline $\begin{array}{c}\text { Decapterus } \\
\text { macrosoma } \\
\text { (round scad) }\end{array}$ & 0.225 & 0.032 & 0.071 \\
\hline $\begin{array}{c}\text { Chanos chanos } \\
\text { (bangus) }\end{array}$ & 0.365 & 0.199 & 0.322 \\
\hline $\begin{array}{l}\text { Auxis thazard } \\
\text { (skipjack tuna) }\end{array}$ & 1.688 & 0.526 & 0.203 \\
\hline $\begin{array}{l}\text { Oreochromis } \\
\text { niloticus } \\
\text { (tilapia) }\end{array}$ & 0.173 & 0.320 & 0.436 \\
\hline
\end{tabular}

$\mathrm{HQ}_{\mathrm{EFA}}<1$ means health benefit from fish consumption $\mathrm{HQ}_{\mathrm{EFA}}>1$ means risk from fish consumption

\section{CONCLUSIONS}

The target hazard quotients for most of the fish and products showed values less than 1, which suggests that health risks were insignificant. All fish and products gave values less than 1 except for $\mathrm{Cd}$ of squid (1.8), As of dried Indian sardine (19.9), squid (1.8), shrimp (3.4), and skipjack tuna (1.7). The accumulation of heavy metals varies with the fish species, and the risk information given to the public allows people to choose from a diversity of fish for a healthy diet. On the basis of omega-3 fatty acids EPA and DHA and heavy metal content, the levels of $\mathrm{Cd}$ in squid and As in dried Indian sardine, squid, shrimp and skipjack tuna, may suggest risk.

It is concluded that to protect people from the deleterious effects of fish consumption and to ensure healthy fish diets, regular monitoring of hazard quotients for fish and products in wild conditions is recommended.

\section{ACKNOWLEDGEMENT}

The study was funded by the Food and Nutrition Research Institute and Science Education Institute. The authors acknowledge the technical assistance of Rosemarie J. Dumag, Sheryl M. Ortiz, Zailla P. Flores and Teresita R. Portugal.

\section{REFERENCES}

Abernathy OCh, Thomas DJ, Calderon LR. Health effects and risk assessment of arsenic. J Nutr. 2003; 133:536S-1538S.

Agree JJ, Vaisanen S, Hannien O, Muller AD and Hornstra G. Hemostatic factors and platelet aggregation after fish-enriched diet or fish oil or docosahexaenoic acid supplementation. Prostag Leukot Essent Fatty Acids. 1997; 57:419-421.

Al Rmalli SW, Harris PI, Harrington CF and Ayub M. A survey of arsenic in foodstuffs on sale in the United Kingdom and imported from Bangladesh. Sci Total Environ. 2003; 337:23-30.

Alina M, Azroma A, Mohd Yunos AS, Mohd Zakiuddin S, Mohd Izuan Effendi $\mathrm{H}$ and Muhammad Rizal R. Heavy metals in selected marine fish and shellfish along the Straits of Malacca. Int Food Res J. 2012; 19:135-140.

AOAC Official Methods of Analysis. AOAC Official Method 991.39, Fatty acids in Encapsulated Fish Oils and Fish Oil Methyl Ethyl Esters. 2005.

AOAC Official Methods of Analysis. AOAC Official Method 996.06, Fat (Total, Saturated, and Unsaturated) in Foods. 2005.

AOAC Official Methods of Analysis. (2005). AOAC Official Method 999.10, Lead, Cadmium, Zinc, Copper and Iron in Foods. 2005.

Beijir K and Jernelov A. Sources, transport and transformation of metals in the environment. In: Friberg L, Nordberg GF, Vouk VB, Eds. Handbook on the Toxicology of Metals. $2^{\text {nd }} \mathrm{Ed}$. Amsterdam: General Aspects; 1986. p 68-74. 
Berry EM. Dietary fatty acids in the management of diabetes mellitus. Am J Clin Nutr. 1997; 66 (Suppl):991s-1007s.

Birch EE, Hoffman DR, Uauy R, Birch DG and Prestidge C. Visual acuity and the essentiality of docosahexaenoic acid and arachidonic acid in the diet of term infants. Pediatr Res. 1998; 44:201-209.

Bonaa KH, Bjerve KS, Straume B, Gram IT and Thelle D. Effect of eicosapentaenoic and docosahexaenoic acids on blood pressure in hypertension. A population-based intervention trial from the Tromso Study. N Engl J Med. 1990; 322:795-801.

Budtz,-Jorgensen E, Grandjean P and Weihe P. Separation of risks and benefits of seafood intake. Environ Health Perspect. 2007; 115:215-221.

Burger J. Assessment and management of risk to wildlife from cadmium. Sci Total Environ. 2008; 389:37-45.

Bustamante P, Cosson RP, Gallien I, Caurant F. and Miramand P. Cadmium detoxification processes in the digestive gland of cephalopods in relation to accumulated cadmium concentration Mar Environ Res. 2002; 53:227-41.

Carvalho ML, Santiago S and Nunes ML. Assessment of the essential and heavy metal content of edible fish muscle. Anal Bioanal Chem. 2005; 38:426-432.

Castro-Gonzales IM. Acidos grasos omega-3: beneficios y Fuentes. Interciencia. 2002; 27:37-50.

Castro-Gonzales MI and Mendez-Armenta M. Heavy metals: implications associated to fish consumption. Environ Toxicol Pharmacol. 2008; 26:263-271.

Chan MH and Egeland MG. Fish consumption, mercury exposure, and heart disease. Nutr Rev. 2004; 62:68-72.
Clarkson WT. The three modern faces of mercury. Environ Health Perspect. 2002; 110 (Suppl. 1):11-23.

Connor SL and Connor WE. Are fish oils beneficial in the prevention and treatment of coronary artery disease? Am J Clin Nutr. 1997; 66 (Suppl.):1020s-1031s.

Connor WE. Omega-3 fatty acids and heart disease. In: Kritchevsky D, Caroll KK, Eds. Nutrition and Disease Update: Heart Disease. Champaign, IL: American Oil Chemical Society; 1994. pp 7-42.

Darlington LG and Stone TW. Antioxidants and fatty acids in the amelioration of rheumatoid arthritis and related disorders. Br J Nutr. 2001; 85:251-269.

Din JN, Newby DE and Flapan AD. Omega3 fatty acids and cardiovascular disease-fishing for natural treatment. BMJ. 2004; 328:30-35.

Domingo JL, Bocio A, Flaco G and Llobert JM. Benefits and risks of fish consumption. Part I. A quantitative analysis of the intake of omega-3 fatty acids and chemical contaminants. Toxicology. 2007; 230:219-226.

EEC. Regolamento no. 466/2001 della Commissione dell' 8 marzo 2001 che definisce I tenori massimi di taluni contaminanti presenti nelle derrate alimentary. Gazzetta Ufficiale delle Comunita Europee, L77. 2001.

Falco G, Llobet JM, Bocio A and Domingo JL. Daily intake of arsenic, cadmium, mercury, and lead by consumption of edible marine species. J Agric Food Chem. 2006; 54:61066112.

FAO/WHO Expert Committee on Food Additives, Arsenic. http://www.inchem.org/ documents/jecfa/jeceval/jec 159.htm. 2005

FAO/WHO Expert Committee on Food Additives, Cadmium. http://www.inchem.org/ documents/jecfa/jeceval/jec 297.htm. 2005 
Foran JA, Good DH, Carpenter DO, Hamilton MC, Knuth BA and Schwager SJ. Quantitative analysis of the benefits and risks consuming farmed and wild salmon. J Nutr. $2005 ; 135: 2639-2643$.

FNRI-DOST. Philippine Nutrition Facts and Figures 2008 by FNRI-DOST, pp 142-174. 2010

Gladyshev MI, Sushchick NN, Anishchenko OV, Makhutova ON, Kalachova GS and Gribovskaya IV. Benefit-Risk ratio of food fish intake as the source of essential fatty acids vs. heavy metals: a case study of Siberian grayling from the Yenisei River. J Food Chem. 2008; 115:545-550.

Goyer AR. Toxic metals and essential metal interactions. Annu Rev Nutr. 1997; 17:37-50.

Groth III E. Ranking the contributions of commercial fish and shellfish varieties to mercury exposure in the United States: implications for risk communication. Environ Res. 2010; 110:226-236.

Harris WS. N-3 fatty acids and serum lipoproteins: human studies. Am J Clin Nutr. 65:16455-16545.

Horrocks LA. Health benefits of docosahexaenoic acid (DHA). Pharmacol Res. 1999; 40(3):211-225.

Horwitz W. AOAC International. Official Methods of Analysis. Vol. II, 39. 17 $7^{\text {th }}$ ed. Maryland, USA; 2000. pp. 7-8.

Horwitz $\mathrm{W}$ and Latimer GW. AOAC International Official Methods of Analysis. Rev. 2, 35. $18^{\text {th }}$ ed. Maryland, USA; 2000. p 8.

Ismail HM. The role of omega-3 fatty acids in cardiac protection: on overview. Front Biosci. 2005; 10:1079-1088.

Kinsella JE, Lokesh B and Stone RA. Dietary $\mathrm{n}-3$ polyunsaturated fatty acids in amelioration of cardiovascular disease: possible mechanisms. Am J Clin Nutr. 1990; 52:1-28.
Kris-Etherton PM, Harris WS and Appel LJ. AHA Nutrition Committee. Omega-3 fatty acids and cardiovascular disease: new recommendations from the American Heart Association. Arterioscler Thromb Vasc Biol. 2003; 23:151-152.

Kris-Etherton PM, Harris WS and Appel LJ. Fish consumption, fish oil. Omega-3 fatty acids, and cardiovascular disease. Circulation. 2002; 106:2747-2757.

Madamba LSP and Pamulaklakin MA. Heavy Metals in Selected Fish Species Collected from Laguna De Bay. Phil J Sci. 1994; 123(2):135-146.

Malasanos TH and Stacopoole PW. Biological effects of omega-3 fatty acids in diabetes mellitus. Diabetes Care. 1991; 14:1160-1179.

Napolitano GE, Ratnayake WMN and Ackman RG. All cis-3, 6, 9, 12, 15octadecapentaenoic acid: A problem of resolution in GC analysis of marine fatty acids. Phytochemistry. 1998; 27:1751-1755.

Nettleton JA and Exler J. Comparison of nutrients in farmed and wild fish and shellfish. J Food Sci. 1992; 57:257-260.

Olsson PE. Disorders associated with heavy metal pollution. In: Leatherland JE and Woo PTK, Eds. Fish Diseases and Disorders Volume 2. United Kingdom: CABI International; 1998. pp. 105-131.

Oomen CM, Freskens EJ, Rasanen L, Fidanza F, Nissinem AM, Menotti A, Kok FJand Kromhout D. Fish consumption and coronary heart disease mortality in Finland, Italy and The Netherlands. Am J Epidemiol. 2000; 151:999-1006.

Papanikolaou CN, Hatzidaki GE, Belivanis S, Tzanakakis GN and Tsatsakis MA. Lead toxicity update. A brief review. Med Sci Monit. 2005; 11:RA329-336.

Prudente M, Kim EY, Tanabe $\mathrm{S}$ and Tatsukawa R. Metal Levels in some commercial fish species from Manila Bay, the Philippines. Marine Poll Bull. 1994; 34(8):671-674. 
Rustan AC, Nenseter MS and Drevon CA. Omega-3 and omega- 6 fatty acids in the insulin resistance syndrome: lipid and lipoprotein metabolism and atherosclerosis. Ann NY Acad Sci. 1997; 827:310-320.

Santiago EC, Africa CR and Pascual AR. Total Mercury in Three Fish Species Sold in a Metro Manila Public Market: monitoring and health risk assessment. Science Diliman. 2009; 21(1):1-6.

Schmidt EB. N-3 fatty acids and the risk of coronary heart disease. Danish Med Bull. 1997; 44(1):1-22.

Stone NJ. Fish consumption , fish oil, lipids, and coronary heart disease. Circulation. 1996; 94:2337-2340.

Storelli MM. Potential human health risks from metals $(\mathrm{Hg}, \mathrm{Cd}$ and $\mathrm{Pb})$ and polychlorinated biphenyls (PCBs) via seafood consumption: estimation of target hazard quotients (THQs) and toxic equivalents (TEQs). Food Chem Toxicol. 2008; 46:27822788.

Storelli MM and Marcotrigiano GO. Interspecific variation of in total arsenic concentrations in elasmobranch fish from the Mediterreanean Sea. Mar Poll Bull. 2004; 48:1145-1167.
Svensson BG, Schutz A, Nilsson A, Akesson $B$ and Skerfving S. Fish as a source of exposure to mercury and selenium. Sci Total Environ. 1992; 126:61-74.

Takhata K, Monobe K, Tada M and Weber PC. The benefits and risks of $n-3$ polyunsaturated fatty acids. Biosci Biotechnol Biochem. 1998; 62(11):2079-2085.

Tecator Manual 1043 Soxtec System HT 6. pp. 10-12, Foss Tecator AB, Sweden.

Tecator Manual Soxtec System 1047 Hydrolyzing Unit. pp. 6-10, Foss Tecator AB, Sweden.

Toft I, Bonaa KH, Ingrebesten OC, Nordoy $A$ and Jenssen T. Effects of n-3 polyunsaturated fatty acids on glucose homeostasis and blood pressure in essential hypertension. A randomized controlled trial. Ann Intern Med. 1995; 123:911-918.

World Health Organization. Methylmercury. Environmental Health Criteria by WHO, 101: 1-80. 1990.

Yashodhara BM, Umakanth S, Pappachan JM, Bhat SK, Kamath R and Choo BH. Omega-3 fatty acids: A comprehensive review of their role in health and disease. Postgrad Med J. 2009; 85:84-90. 